\title{
Mythologeme as a Sign in the System of Cultural Concepts
}

\author{
Irina B. Rubert* \\ St. Petersburg State University of Economics \\ 30/32 Nab. kanala Griboedova, St. Petersburg, 191023, Russia
}

Received 10.09.2015, received in revised form 11.11.2015, accepted 06.12.2015

\begin{abstract}
The article deals with the problem of the role of mythologeme as a sing within its traditional definition in the system of cultural concepts. The author introduces linguistic and semantic insight in the structure of mythologemes and explains the difference between mythological and rational thinking under the process of language conceptualization of the world. The work also contains the classification of mythological archetype content; the analysis of mythologeme performance and its possible semantic changes during the development of cultures. As a conclusion the author gives a detailed characteristics to three types of mythologeme (i.e. predicate mythologeme, graphologeme and prototypic mythologeme) and marks their main functions and roles in the system of culture.
\end{abstract}

Keywords: myth, culture, mythologeme, mythological archetype, predicate mythologeme, graphologeme, prototype mythologeme, symbolism.

DOI: 10.17516/1997-1370-2015-8-12-2982-2988.

Research area: philology.

\section{Introduction}

The term "myhtologeme" has come to an active use in philology relatively recently and its understanding is far from being precise. Since the word "mythologeme" represents both term and meta-term in the language (in that sense it coincides with such words as "theory", "science" and etc.), a productive way for its insight is a description against a backdrop of the related forms of thinking and in series of imaginative complexes of vision. The main difference between mythologemes and myth itself lies in the absence of the narrative development since the meaning of an event is transformed into the event of meaning in mythologeme.

Mythologemes play an extremely important role in the human culture. As a social being, a person is indicated by certain ideological, moral and ethical, physiological guides relevant to a particular social and cultural situation in the world: for example, during war periods the archetype of self-sacrificingness (or of a hero) for the benefit of the country is frequently and actively used; as for the modern world, the pursuance of personal success, leadership and wealth is implanted.

Taking into account that the study of mythologemes may well be conducted in different

(c) Siberian Federal University. All rights reserved

* Corresponding author E-mail address: dept.olgf@unecon.ru 
ways (i.e. searching for a particular set of mythologemes representing separate archetypical ideas, thesaurus compilation or studies dedicated to analysis of mythologemes as linguistic and cultural means of manipulation), in this article we are of the opinion that the mythologeme should be described within linguistic and semiotic framework and showed as a sing in its traditional definition.

\section{The power of mythologeme as a sign: semantic and cultural approach}

Looking at the world of mythology as composed of objects of equal rank non-divided into features and one-fold Yu. M. Lotman has come to the conclusion that myth is assimilated to the language of proper names in their utmost abstraction, while the main mechanism of mythological thinking is the process of nomination (Lotman, 1970). The statement allows defining a special mythological layer in the system of a natural language. The core of this layer is constituted by personal names with mythological subjects under them. Mythologeme further on we shall call a subject-logical structure under this name, including actants, predicate and sirconstants which implicitly contains a component of mythological narration on a certain event (Greek $\mu v \theta 0 \varsigma$-'narration') (Mif. Entsiklopedicheskaia statia, 2012). Thus the Mythologeme correlates to a notion of a structural model of myth by K. LeviStross (Levi-Stross, 1994: 353) in ethnology and comparative mythology; it correlates to the notion of mythological archetype in the fine arts critics and literature critics, and correlates to the notion of a fairy tale motif by V.Y. Propp (Propp, 2001: 34 ) in structural analyses of a fairy tale.

A subject-and-notion structure is understood under the mythologeme, it implicitly contains a narration of an event with mythological correlations explicated linguistically or graphically. From the linguistic point of view, the Mythologeme is described as a mythological subjective mythonym, name for a mythological event narrated. For example, a mythonym Narcissus differs from the corresponding floronym (narcissus) as it presupposes a narrative about a young man who died of an unshared love to his own reflection in the water.

Mythologeme pastes two or more content plans into one plan of expression. One of the content plans correlates to a personifying mythological name and the other one (ones) correlate(s) to a symbolic entity. The basic difference of the latter from the concept is seen in the main way of categorization of reality.

An analytical approach to the basics of the search of integral and differential features of the examined situations and comparing them to the present mental representations, including the models of these situations into the system of genus-species and cause-and-effect relations, abstraction of the phenomena of reality to the level of generalized conceptual categories is characteristic of the modern person. For mythological thinking the search of the similar, kin traits between the phenomena is characteristic, it searches the features allowing to sometimes uniting separate kin phenomena into on class merely because of their existence. For example, the ring may symbolize wedding, circle of life, the Earth, the Universe. Such an "analogical" method of looking at reality has created some kind of order so vital in the struggle against the chaos of the hostile world.

A lot of mythological analogies can be traced in history. Sometimes, the mythological identification of events seems to be a coded history projected into the future. For example, there is a legend about the Titans, ancient people who were punished by God who made them drown in the ocean. In 1914 HMS "Titanic" with many rich, famous and mighty people drowned in 
the Atlantic Ocean. There is nothing supernatural in this supposition knowing that the myth evokes consequences on the deep, emotional level of a psychic personality, thus, defining models of personal conduct against a historical background.

Mystically minded people may interpret historical facts in a mythological way. Nevertheless, there is a minimum of logic contained in such interpretations; the interpretations of events through a mythological subjective prism are carried out on the basis of an "analogy" principle.

If the modern rational mind allocates the taxons according to the central (intentional) features of the notions, the ancient mind used mythological names as the "genus" names of the whole range of contiguous or even distantly similar notions (for example, Poseidon - water, sea, storm, etc.).

The well-known frequency of mythological motifs in the people's communication of different times may serve as the proof of the stability of a mythologeme as a basis of the psychic fidel structures.

Mythologeme occupies an important position among the cultural concepts. Concept is understood (after Yu. S. Stepanov) as the "basic cell of culture in the mental world of a person" (Stepanov, 1997: 43). Concepts arrange reality not only at the personal, but also at the national level, evolving with the development of society. The juxtaposition of the "middle" and "outer world" characteristic of the language categorization of the world in the mind of Germanic peoples defines the co-ordinates of the whole picture of the world. The tenement of people in Germanic mythology was called "Middle World", Midjungarths (Goth.) Middangeard (Old Eng.), Mithgarthr (Old Isl.), Mittelgart (Ohg.) (from Gart, geard - a hedged place). This middle world, settled and ordered by the humans, was juxtaposed to the outer space, the kingdom of evil forces and monsters (Utgarthr). Though modern geographical view differs from the ancient picture of the world, the old Germanic model is widely resorted to in ideology. The pictures of civilized democratic world compared with the "world of monsters" helps to promote mass media message of "monsters" in "nondemocratic" parts of the world and approve of fighting them.

So, the structure of a mythological archetype contains the name symbolizing:

1) a certain situation;

2) a metalingual code to the decoding of this situation (excluding monosemy);

3) the aim of decoding, i.e. the situation which must be explained by way of this myth.

As arule, it is notapersonally marked situation but a socially meaningful one. The distinctive feature of the archetype is that it can't be reduced to a one well-known myth as a Mythologeme. Such is for example the Mythologeme of the "World Tree". The mythologeme similar to the "World Tree" can't be reduced to one concrete myth, it can only be reconstructed.

Mythologeme, perhaps, not even acknowledged by a native speaker, is revealed in separate emotionally marked units. Thus, a word "nightmare" in its origin goes back to the name of an evil monster of Scandinavian and Celtic mythology Mare (Mora).

Historically enriched with the multiple cultural meanings, the mythologeme may acquire different connotations. For example, Swastika, the name of which goes back to the Sanskrit $s u$ (good) and asti (genesis), initially carried a positive emotional load which was cultivated by different peoples. The right-hand Swastika was traditionally connected to the Artemis (Diana in Roman mythology), in China in symbolized "Ing", in Scandinavian cultures it was related to the zig-zag lightning and stood for Thor. Usage of Swastika by the Nazis turned the emotional load 
into a negative one. The mythologeme acquires characteristics of a sign with connotative components.

The multiple functionality of a myth makes it both the source for the universal historical and artistic means of interpreting the world, a descriptive means of learning and explication of the reality by way of constructing its models, and owing to the concentration of a positive experience in the myth (mostly cryptologically coded) of a kind of an imperative, a blueprint containing a prescription for a human being or a social group.

The frequency of mythological motifs, subjects, images in literature of different times and peoples may serve as the proof of the "cognitive reality" of the fidel structures of mentality which operate with the help of mythologemes. This fact justifies the conclusion that mythology is a "fertile soil" for the creation of literary images, that the world fiction inherits mythological motifs. This fact is true when an author possessing a broad outlook can't but to get acquainted with mythological heritage of the past. However, this coin may have another side. Why is mythology so up-to-date, what makes it a bottomless well for the creativity?

\section{The semiotic structure of mythologeme: on the question of classification}

Being a sign, the Mythologeme includes a name, a denotatum and a designatum. The symbolism of the Mythologeme is also revealed in its ability to possess a connotative aspect.

There are three types of the Mythologeme: a predicate, a prototype and a graphologeme.

\section{1) Predicate mythologeme}

The notional core of this mythologeme tends to form a logical structure and the central explicate of which is predicate. The mythologeme of way serves as a vivid example of this type.
The extremely generalized notion of a way, correlating to travel of mythological personages (such as Ulysses) is contained in the name, the denotative component includes a strictly divided logical structure, in which the actants are included (the acting personages, setting off on a voyage, traveling or just going to set off), a predicate (the traveling) and sirconstants (which correspond to the adverbial modifiers of place, time, and manner, and in case of a mythologeme presuppose some by-conditions, such as the landscape, obstacles, parameters of movement, which are the speed, the time, the distance, etc.).

The designative component also includes the notion of different types of predicate, as the movement in both its figurative (travel in space) and literal (life way) meanings, and all these types (traveling, running, pilgrimage, exile, conquest, returning) are included into the structure of different texts, binding them with the united network of sense.

According to Ch. Pierce's classification a predicate mythologeme may be referred to symbol signs (Pierce, 2009: 88-95). Other examples of a mythologeme of this type, when a predicate defines a possible set of sirconstants and actants are the mythologemes of a game, a theatre, a dance, a negotiation.

\section{2) Graphologeme}

The central explicant of the mythologeme of this type which we use when interpreting it, is the symbol tending to the graphical explication, while its sensual core is close to a denotative component. The mythologeme of a Circle illustrates the graphologeme. The contents of a denotative component is the extremely generalized image of a circle, while some images of a circle are included into the designative component: these are a geometric figure (the notions of a circle, radius, diameter, the formula of the circular area, etc.), properties associated with something 
circular (completeness, symmetry, infinity), and a range of round objects (the sun, the moon, a wheel, a ring, etc.). The latter may be realized in the texts in both literal and figurative meaning (e.g. the sun - the life, the moon -the death) and posses a broad sensual rate. In the Pierce's terminology a graphologeme is an icon sign (Pierce, 2009:88-95); Ch. Morris calls this type of sign a characteristic one (Morris, 1983: 57).

\section{3) Prototypic mythologeme.}

Denotative and designative components of this type of a mythologeme are close in some prototype, which makes up its sensual core. The central explicant of prototypic mythologeme is the actant which often corresponds to the sirconstant and defines the predicate. Mythologeme of water is the example of this type. The denotative components correlating with the name include the general non-divided notion of water, while the designative component contains a set of discreet images of the essence of water, its chemical formula, properties (liquidity, fluidity, evaporation capacity, etc.) and different forms of its existence (sea, river, rain, etc.). The latter are contained in different types of texts both mythologic and nonmythologic. According to Pierce's classification the prototypic mythologeme correlates with index (Pierce, 2009:88-95). Besides the mythologeme of water the mythologemes of the world tree and fire refer here.

The symbolism of the mythologeme is multilevelled and mediated. The structure of the Mythologeme is divided into separate sensual layers; and the layer which refers to the content plan of one of them is the expression plan for the other one. Thus, the examination of the Mythologeme of "a Circle" in the expression attitude corresponds to the notion of a circle, which on the next level corresponds to the notions of the Sun and the Moon that on the even higher level correspond to the notions of Life and Death.
While the units on the higher levels have their own names on the lower levels of expression.

One more important characteristic feather of the mythologeme as a sign is its asymmetry. One significatum (circle) corresponds to the indefinite number of signifiers (the Sun, the Moon, a Ring, a Wheel), each of them is the singificatum for the new layer of signifiers (Life, Death, Infinity). Thus, mythologeme goes beyond the text and returns to it transforming it and being itself transformed in it. The latter means that the mythologeme is purely a linguistic notion.

The other important thing is the role (functions) of mythologeme in the culture. As man linguists and culturologists claim the life of the mythologeme in the culture is presented in its cognitive function (as an a priori argument), axiological (since the mythologeme contain selected sufficient information needed for the social self-development), nominative (acceptance of the world in the form of names and reformation of the world though renomination), communicative (as a dictionary for communication), regulative (as an image of prohibition-and-allowance and as an instrument of hierarchization). Aesthetic function of the mythologeme is of a great importance since it reflects the rules of elements combination and the regimes of acquisition for expressive means of language and cultural antiquity.

\section{Conclusion}

As it is stated in this article we tend to describe the mythologeme as a narrative and conceptual complex which implicitly contains narration of some events bearing mythological correlates. Any mythologeme is characterized by its ability to interconnect in one and the same plan of expression two or even more layers of content: one of them may relate to a personifying mythological name while the other (others) - with a symbolizing element. Thus, the mythologeme seems to us as a closed semiotic system aimed at 
forming and regulating of a certain chronotope and serving as a part of the world view as a whole.

To draw the line, we highlight the important role of the mythologeme in the system of cultural concepts. Being a social phenomenon, the mythologeme should further be described from the point of view of social and cultural studies This article claims to be only a fragment of a more in-depth study, contributing to cultural concepts analysis and study of their nature, characteristics and functions.

\section{References}

Biblia. Knigi Sviashhennogo Pisaniia Vethogo i Novogo Zaveta (The Holy Bible. The Holy Books of the Old and New Convenant). Moscow: Mezhdunarodnyi izdatelskii centr pravoslavnoi literatury, 1994.

Ch. Morris Osnovaniia teorii znakov / Semiotika (The Foundations for the Theory if Sings / Semiotics). Moscow: Raduga, 1983. Pp.37-90.

Ch. S. Pirs Chto takoe znak? /Perevod A.A. Argamakovoi // Vestnik Tomskogo gosudarstvennogo universiteta. Filosofiia. Sociologiia. Politologiia (What is a Sing?/Translated by A.A. Argamakova // Journal of Tomsk State University. Philosophy. Sociology. Political Studies). Tomsk: Izd-vo Tomskogo gosudarstvennogo universiteta, 2009. № 3 (7). Pp 88-95.

Yu. S. Stepanov. Konstanty. Slovar' russkoi kultury (Constants. The Dictionary of the Russian Culture). Moscow: Jazyki russkoi kultury, 1997. 824 p.

K. Levi-Stross Pervobytnoe myshlenie (Primitive Thinking). Moscow: Respublika, 1994. 384 p.

L. E. Tailor. Pastoral and Anti-Pastoral Patterns in John Updike's Fiction. London - Amsterdam, 1971.

Mif. Entsiklopedicheskaia statia (Myth. The Entity in the Online Encyclopaedia). Available at http://dic.academic.ru/dic.nsf/enc_philosophy/733\%DD\%9C\%D\%98\%D\%A4

P. A. Florenskii Imena.(Names). Kostroma, 1993.

V. Ja. Propp Morfologiia volshebnoi skazki.(The Morphology of a Fairy-Tale). Moscow: Labirint, 2001. 92 p.

Yu. M. Lotman Stat'i po tipologii kultury: materialy k kursu teorii literatury. (Articles on the Culture Typology: Works for the Course of Literary Theory). Tartu, 1970. V.1. 


\section{Мифологема как знак}

\section{в системе концептов культуры}

И.Б. Руберт

Санкт-Петербургский государственный экономический университет Россия, 191023, Санкт-Петербург, Набережная канала Грибоедова, 30/32

В статье рассматривается вопрос о роли мифологемы как знака в его классическом понимании в системе концептов культуры. Автор представляет лингвосемантическое понимание структуры мифологемы, объясняет различие между мифологическим и рачиональным мышлением в рамках процесса языковой концептуализации картины мира. В работе также изложена классификация содержания мифологического архетипа (номинации); анализируется поведение и возможное семантическое изменение мифологемы в проиессе развития той или иной культуры. В заключение автор подробно характеризует три типа мифологемы (предикативная, графологема и прототипическая) и называет основные функции и роли, которые она выполняет в системе культуры.

Ключевые слова: миф, культура, мифологема, мифологический архетип, предикативная мифологема, графологема, прототипическая мифологема, символизм.

Научная спещиальность: 10.00.00 - филологические науки. 